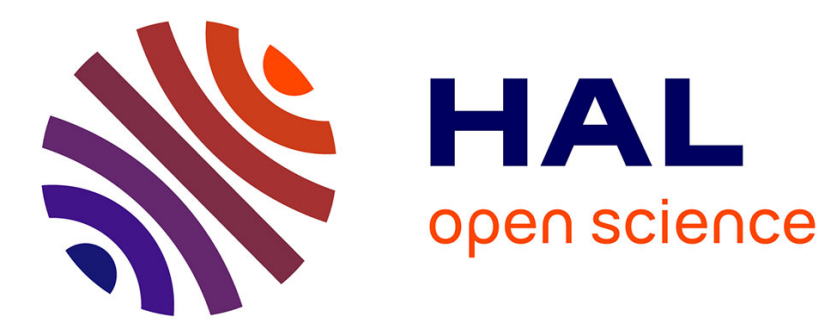

\title{
STANDARDS FOR QUANTITATIVE X-RAY MICROANALYSIS OF BIOLOGICAL SPECIMENS
}

\author{
W. de Bruijn
}

\section{To cite this version:}

W. de Bruijn. STANDARDS FOR QUANTITATIVE X-RAY MICROANALYSIS OF BIO-

LOGICAL SPECIMENS. Journal de Physique Colloques, 1984, 45 (C2), pp.C2-469-C2-472. 10.1051/jphyscol:19842107 . jpa-00223774

\section{HAL Id: jpa-00223774 https://hal.science/jpa-00223774}

Submitted on 1 Jan 1984

HAL is a multi-disciplinary open access archive for the deposit and dissemination of scientific research documents, whether they are published or not. The documents may come from teaching and research institutions in France or abroad, or from public or private research centers.
L'archive ouverte pluridisciplinaire HAL, est destinée au dépôt et à la diffusion de documents scientifiques de niveau recherche, publiés ou non, émanant des établissements d'enseignement et de recherche français ou étrangers, des laboratoires publics ou privés. 
JOURNAL DE PHYSIQUE

Colloque C2, supplément au n²2, Tome 45, février 1984

page $C 2-469$

STANDARDS FOR QUANTITATIVE X-RAY MICROANALYSIS OF BIOLOGICAL SPECIMENS

\author{
W.C. de Bruijn \\ Centre for Analytical EZectron Microscopy, Laboratory for EZectron Microscopy, \\ Rijnsburgerweg 10, 2333 AA Leiden, The Netheriands
}

\begin{abstract}
Résumé - Il est proposé d'utiliser des particules sphëriques échangeuses d'ions comme étalon pour estimer la proportion des divers êléments dans les tissus biologiques.

Abstract - The use of ion exchange beads is proposed as standards for the estimation of various elements in biological tissues.
\end{abstract}

Elements to be detected or quantitated in biological tissues occur in three forms: as free ions or salts, in a crystalline phase, and bound to a matrix. For the latter category a standard system using chelex 100 ion exchange beads is proposed. Cations can be attached in a controlled way to such an artificial polystyrene divinyl benzene matrix, furnished with negatively charged iminodiacetate functional groups by replacing the sodium ions present in the commercial product.

In Fig. 1 beads measuring 35-75 $\mu \mathrm{m}$ in $\phi$ are shown in the SEM-mode as standards for bulk analysis, attached to a graphite plate with graphite glue (Leit $C$ ). The analysis of Co-loaded beads is given in Fig. 2. Loading conditions from salt solutions are described elsewhere (1).

The binding is controlled mainly by the $\mathrm{pH}$ of the reaction. After loading, the excess of the equilibrium solution can be washed away by rinsing with a buffer having the same $\mathrm{pH}$ as the equilibrium solution. When the beads are maximally loaded, the concentration of the various elements vary - according to the differences in affinitybetween 2 and $15 \mathrm{w} / \mathrm{w} \%$ (as far as we have measured them), but almost every concentration below the maximum value can be obtained by changing the equilibrium conditions. The concentration on the maximally loaded beads was determined at 40 or 60 $\mathrm{kV}$ on 35-75 $\mu \mathrm{m} \emptyset$ beads with either the pure metal or copper as a reference. On identical samples the concentration was determined by neutron activation (Interuniversitair Reactor Instituut, Delft; Table I).

TABLE I. Mean maximum concentration on Chelex ${ }^{100}$-beads (in $\% \mathrm{w} / \mathrm{w}$ ).

\begin{tabular}{lrrrrrrrrrr}
\hline & $\mathrm{Zn}$ & $\mathrm{Cu}$ & $\mathrm{Ni}$ & $\mathrm{Co}$ & $\mathrm{Fe}$ & $\mathrm{Mn}$ & $\mathrm{Ca}$ & $\mathrm{Mg}$ & $\mathrm{Na}$ & $\mathrm{H}(\mathrm{Na})$ \\
\hline $\begin{array}{l}\text { Neutron acti- } \\
\text { vation }\end{array}$ & 12.2 & 12.7 & 9.8 & 12.1 & 11.5 & 9.4 & 6.5 & 4.1 & 6.3 & 0.01 \\
\hline $40 \mathrm{kV}$ & 13.0 & 13.9 & 12.9 & 10.5 & 11.5 & 10.5 & 6.2 & 3.7 & $-\cdots$ & 0 \\
\pm S.D. & 2.3 & 1.6 & 0.6 & 0.5 & 0.6 & 0.5 & 0.6 & 1.8 & & \\
\hline $60 \mathrm{kV}$ & 12.6 & 13.7 & 11.5 & 10.5 & 11.4 & 8.2 & 5.5 & 4.9 & -- & 0 \\
\pm S.D. & 0.8 & 0.5 & 0.4 & 0.4 & 0.7 & 0.5 & 0.5 & 0.7 & & \\
\hline
\end{tabular}

In the spectra sometimes some residual $\mathrm{Cl}$ concentration is present in addition to the requested peak, as in most cases chlorine salts are used for the exchange. The The use of nitrates will prevent that. 

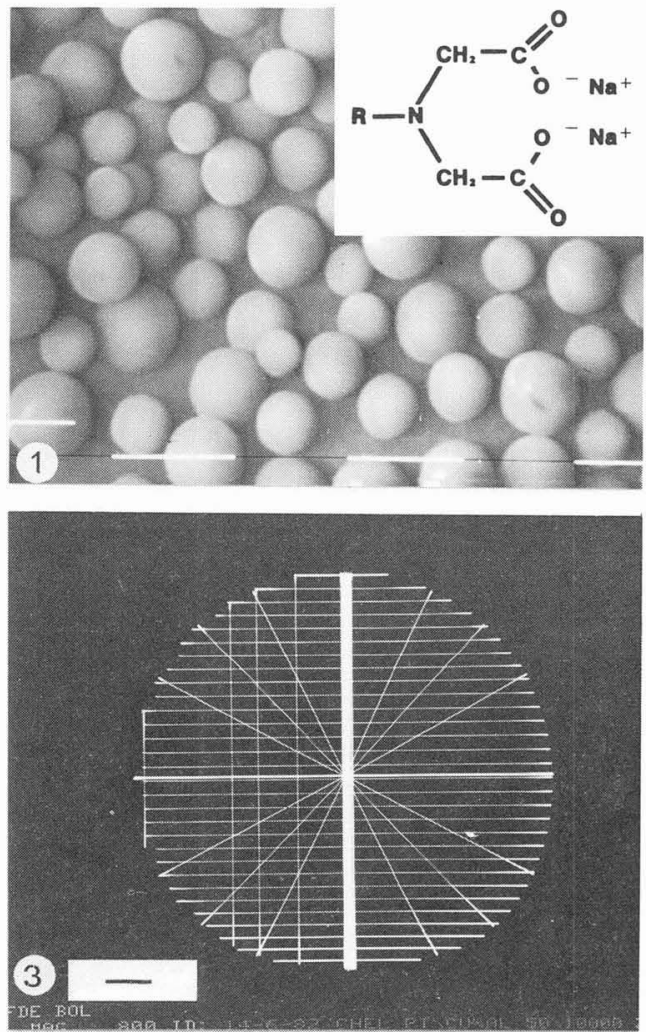

2

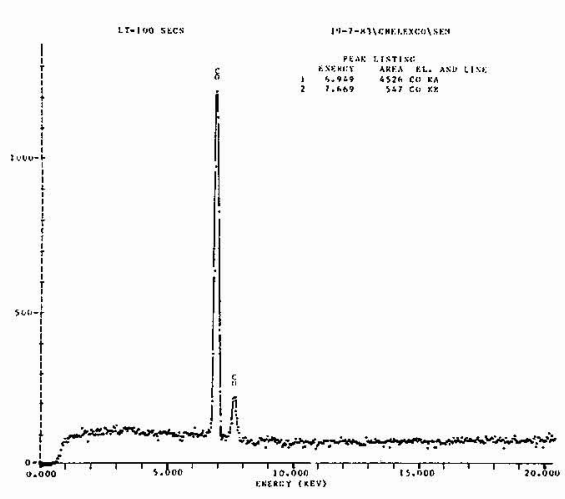

4
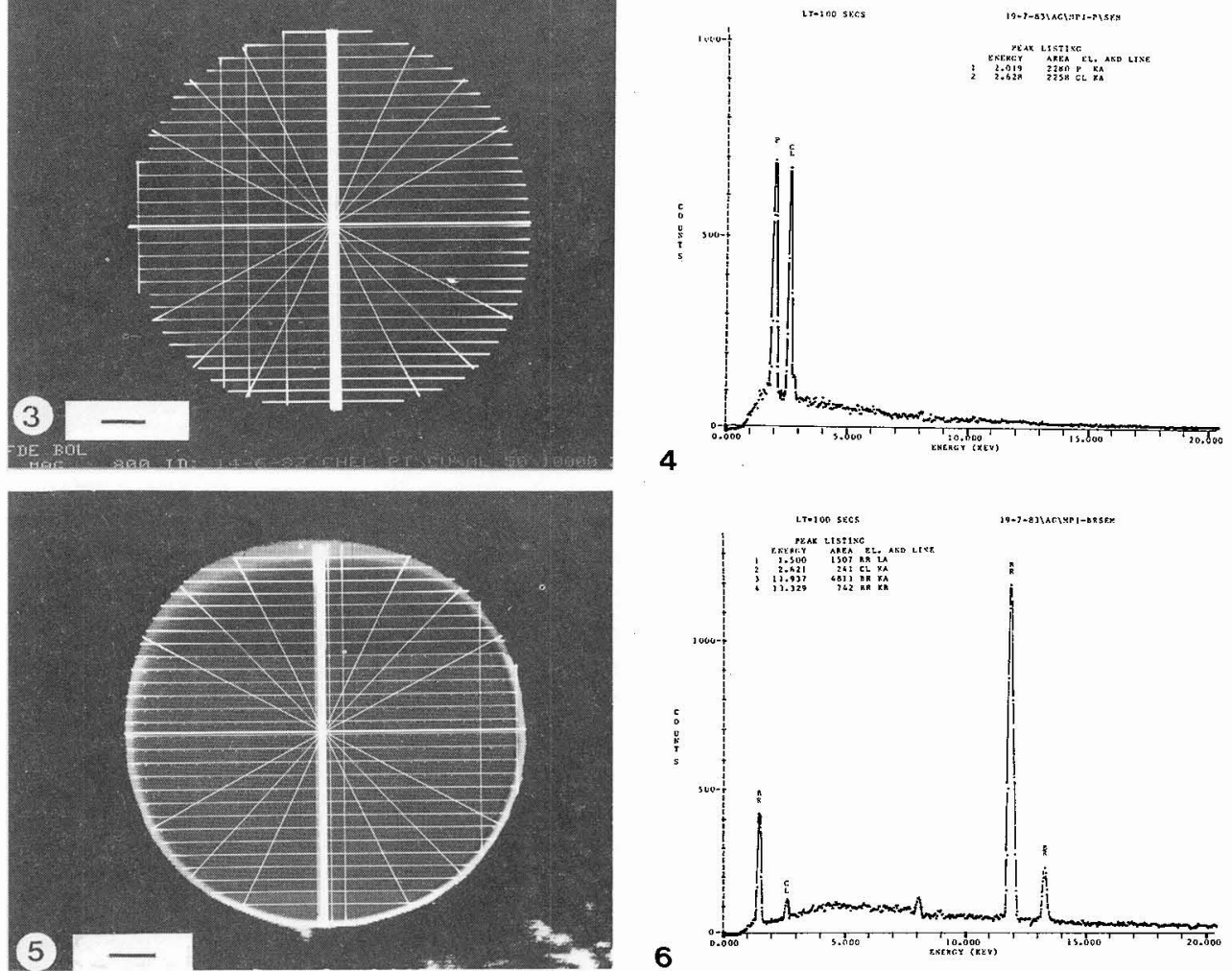

Fig. 1. Chelex beads on a graphite substrate in SEM-mode. Bar: $100 \mu \mathrm{m}$. Inset: functional group equilibrated with $\mathrm{Na}^{+}$.

Fig. 2. Spectrum of cobalt-loaded Chelex beads $60 \mathrm{kV}, 100 \mathrm{~nm}$ spot-size. The conversion of the $\mathrm{Na}$ into $\mathrm{Co}$ beads is complete. The cobalt concentration was estimated to be: 10.5 (or 12.1)\% (Table I).

Fig. 3. P.R.C.-program for measuring beads and X-ray analysis in the centre.Bar: $10 \mu \mathrm{m}$.

Fig. 4. Ag-IIP 1-beads loaded with phosphate, spectrum taken at $60 \mathrm{kV}, 100 \mathrm{~nm}$ spot $\phi$.

Fig. 5. Superimposed images of a bead and its measuring by the P.R.C.-program, to demonstrate the accuracy of the measurement. Bar: $10 \mu \mathrm{m}$.

Fig. 6. Ag-MP 1-beads loaded with bromine, which more completely removes the corimercially present chlorine than the phosphate did. $60 \mathrm{kV}, 100 \mathrm{~nm}$ spot size. 

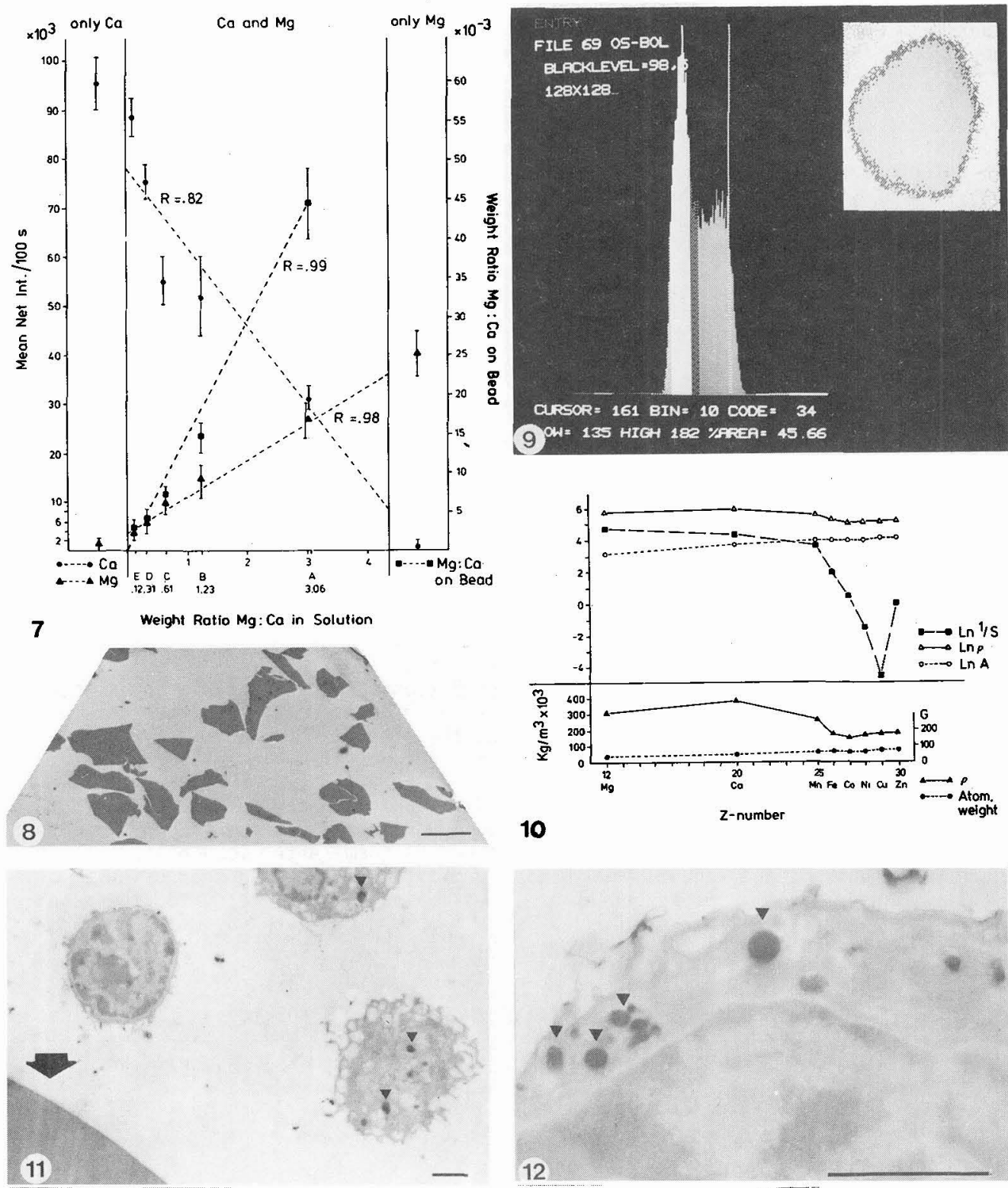

Fig. 7. ReTation between the calcium and magnesium within one bead, with five different mutual ratios, and beads with only calcium or magnesium (Edax, Edit-EM ratio program) SEM-mode.

Fig. 8. Ultrathin section with bead-fragments containing both $\mathrm{Ca}$ and $\mathrm{Mg}$ (ratio $\mathrm{E}$ in Fig. 7). Results given in Table II (section 3).

Fig. 9. I.P.P.-measuring program estimating the surface of the cross-sectioned Chelex bead containing osmium. Reduced Raster Program. $M=133.333 x$

Fig.10. Relation between the determined specific gravity of the loaded beads $(\rho)$, the selectivity coefficient (S) and the atomic weight (A).

Fig.11 Pt-containing monocytic granules revealing peroxidatic enzyme-activity ( $\nabla$ )

and 12. co-embedded with Pt-containing Chelex beads ( G). Glutaraldehyde fixation. Unstained section. $80 \mathrm{kV}$. Bar: $10 \mu \mathrm{m}(11)$. Bar: $1 \mathrm{~mm}(12)$. 
Beads with quaternary ammonium groups attached to a similar styrene divinyl benzene copolymer lattice are available (Bio-Rad, AG-MP 1) that bind anions, such as P03-, $\mathrm{Br}, \mathrm{SO}_{4}^{-}$, and $\mathrm{CN}^{-}$, to that matrix. In spectra of such beads again some residual chlorine is observed being the commercial counter ion, which is not completely removed. Sodium, the commercial counter ion of the negatively charged chelex 100 bead, is apparently not detected due to the bad detection conditions for that element with EDS detectors (Figs. 4 and 6 ). The AG-MP-1 beads to which anions are attached have not yet been tested by a reference system, partialiy due to the fact that pure elements are hard to obtain to perform the same X-ray microanalytical determination, partly due to the fact that we have not yet been able to remove the counter ion $\mathrm{Cl}$ completely.

Besides its use as standard in combination with bulk specimens, such beads can be used as testobjects for automatic measuring-programs, integrating morphometry and X-ray analysis. Such as the Tracor Northern Program P.R.C. (Figs. 3 and 5). Also two elements can be attached to the bead matrix at the sarie time. We offered $\mathrm{Ca}^{2+}$ and $\mathrm{Mg}^{2+}+$-jons to known amounts of 20-30 $\mu \mathrm{m} \phi$ beads in a total concentration of $0.54 \mathrm{M}$ and varied the mutual molar ratio between $\mathrm{Ca}$ and $\mathrm{Mg}$ from 1:5, via $3: 3$ to 5.1 , and measured the elemental $\mathrm{Mg} / \mathrm{Ca}$ ratio. The regression coefficient was 0.99 (Fig. 7). For the biological specimens to be observed in the CTEM-mode the beads are excellent for co-embedding with the tissue to be analysed.

To embed the beads, they were added directly to the final monomer containing the tissue to be investigated, as a dry milled powder or soaked with epoxy propane. In Fig. 8 such ultrathin sectioned beads are shown. In this case such beads were used to test the homogeneous distribution of the elements $\mathrm{Ca}$ (and $\mathrm{Mg}$ ) by comparing 5 point analyses in each cross-sectioned bead in different sections (Table II). Although the SD values are larger than those for the values in Table I, due to the restricted analysed volume in the cross-sections, it can be considered acceptable for a commercial product, not made for such a precision. It can be observed that the Mg values measured in these ultrathin sections approach the minimal detectable limit of the system; whereas the values in the bulk specimen were easily detectable (Fig. $7, E$ ).

To demonstrate that valuable parameters for X-ray analysis can be obtained with this system, we determined the density of the $(35-75 \mu \mathrm{m} \not)$ beads in the vacuum-dried form, loaded with 12 assorted cations and the unloaded $\mathrm{H}^{+}$form. After loading and carefu? washing aliquots of the vacuum-dried beads were carefully weighed and, using a Coulter Counter system, the number of beads was determined. By measuring the mean circumference of several hundred loaded beads in SEM micrographs by using an $X-Y$ tablet, their mean dry volume was determined. The density values were within the range given by others (Fig. 10).

MEAN Ca AND Mg COUNTS IN ULTRATHIN SECTIONED BEADS/100s Table I I

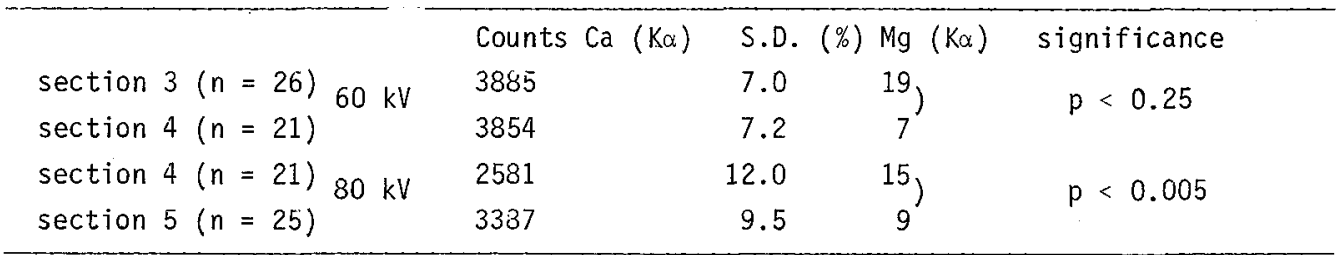

Quite recently such cross-sectioned beads are used as a test-object for the semiautomatic I.P.P.-analysis programs, for the acquisition of both the surface and the mean concentration of elements in cell organelles in ultrathin sections (Fig. 9). The presence of, in this case, Pt-containing Chelex beads between a cross-sectioned cell population with $\mathrm{Pt-containing} \mathrm{reaction} \mathrm{products} \mathrm{from} \mathrm{a} \mathrm{cytochemical} \mathrm{reaction} \mathrm{is}$ shown in Figs. 11 and 12.

References:

1. De Bruijn, W.C., (1981) Ideal standards for quantitative X-ray microanalysis of biological specimens. SEM/II, 357-367 (SEM Inc.AMF 0'Hare Chicago, IL 60666, USA). 